\title{
Matthew and the Torah in Jewish society
}

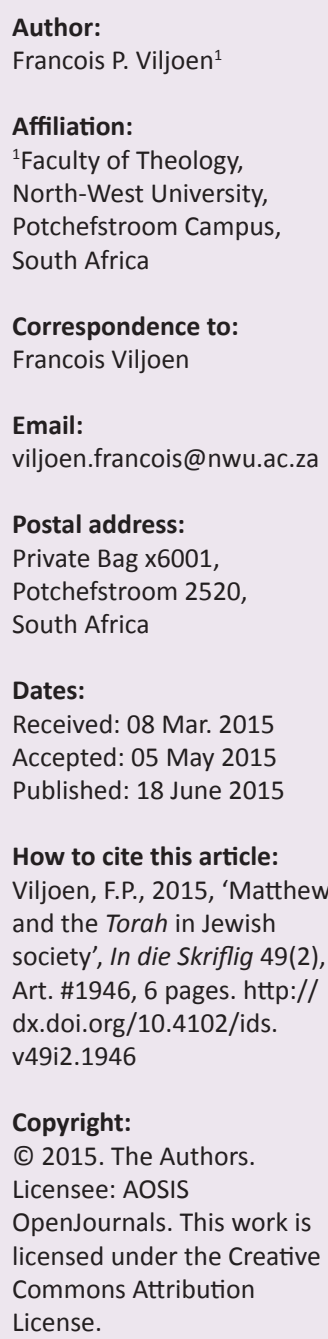

The role of the Torah is the subject of a full-scale discussion in the first Gospel. This article investigates the socio-historical setting that produced this text with such an emphasis on Torah observance. To address these issues, the Matthean text is read against its socio-historical setting to discover issues that were prevalent in the community where the text was produced and read. The Matthean community is plotted within the Jewish religious society, focussing on the role of the Torah within this society. It is argued that the crisis of $70 \mathrm{CE}$ led to a reconsideration of the correct interpretation of the Torah. The Jewish society was fragmented and this led to an urge to consolidate. During these developments the Torah was used by newly formed communities to define their norms of existence against others. In the first Gospel, the author defines his and his community's position on the terms of specific Torah observance. The narrator assures his community of the correctness of their conviction to follow the teachings of Jesus.

Matteus en die Torah in die Joodse samelewing. Die betekenis van die Torah is die onderwerp van 'n grootskaalse bespreking in die eerste Evangelie. Hierdie artikel ondersoek die sosiohistoriese situasie wat aanleiding gegee het tot die ontstaan van hierdie teks wat soveel klem op die onderhouding van die Torah plaas. Om hierdie vraagstuk te ondersoek, word die Matteusteks in sy sosio-historiese konteks gelees ten einde die heersende vraagstukke in die gemeenskap waarbinne die teks ontstaan het, te identifiseer. Die Matteusgemeenskap word binne die Joodse godsdienstige gemeenskap gesitueer met die fokus op die Torah in daardie gemeenskap. Die artikel voer aan dat die krisis van $70 \mathrm{AE}$ tot die herbesinning van die korrekte interpretasie van die Torah gelei het. Die Joodse gemeenskap was gefragmenteer en dit tot ' $n$ strewe na konsolidasie gelei. Te midde van hierdie ontwikkelings, is die Torah deur nuut-gevormde gemeenskappe gebruik om hulle eie norme van bestaan teenoor dié van ander te definieer. In die eerste Evangelie definieer die outeur sy en sy gemeenskap se posisie in terme van spesifieke Torah-onderhouding. Die verteller verseker sy gemeenskap van die korrektheid van hulle oortuigings om die leringe van Jesus na te volg.

\section{Introduction}

Quite extensive research has been done on the Jewish society of the late Second Temple Period (e.g. Brown 1997; Cohen 2006; Saldarini 1994; Stanton 1992; Wright 2013), which provides a useful overview of the political, social, religious and philosophical worlds of the New Testament era. Obviously these depictions of the situation are constructed based on available sources from this era. ${ }^{1}$ From these sources a general idea of this situation can be constructed, although the more localised situation of the first Gospel is more difficult to determine. There is indeed very little directly known about the community in which the first Gospel was written, ${ }^{2}$ although most scholars agree that the narrative of Jesus and his disciples reflects, although partly, the experience of the Matthean community.

The assumption of this article is that the debate about the Torah, as described in the first Gospel, partially reflects this unstable political and religious situation in which this document originated. ${ }^{3}$ The interpretation of the Torah seemingly played a significant role in the religious turmoil of those times.

1.When reading literature in which different groups are described, one has to realise that it is not clear to what extent these groups were constructed by the authors who promote their own groups or criticise their opponents and how much their description meets reality.

2. Most commentaries on Matthew have brief sections about some aspects of the Matthean community such as the relationship between the community and Judaism, the nationality of its members (Jewish, Gentile or both) and its geographical location. However, these constructions are mainly based on internal evidence of the text itself.

3.In my view, the strict distinction between Judaism as a religion of the Law and Christianity as religion of love, is inaccurate. The first Gospel deals extensively with the importance of adhering to the Law, but as interpreted by Jesus. The double-love commandment (Mt 22:34-40) describes love as the essence of the Law. 
In this article broad outlines of the probable religious situation in which the first Gospel originated and what role the Torah played in it is postulated. When considering the setting or community involved in the Gospel, one should do this with great caution. The implied audience may not fully overlap with its historical audience. The internal evidence also does not tell us whether we are dealing with the views of the author or that of the addressees or both. Although it is usually assumed, we also are not sure whether the author lived amongst the addressees.

\section{The Torah as feature of division}

It seems that the newly formed groups used the Torah to justify their parting from other groups and to define their norms of existence. Their rivalry very much centred on the correct interpretation of the Torah. My construction is that the Torah became a feature of division between different groups and that it was used as boundary marker.

In reaction to the Jewish revolt, Rome destroyed Jerusalem, the temple and the temple service in $70 \mathrm{CE}$. This left the Jewish community bewildered. The Jews struggled to come to terms with their loss, and probably entertained the question of whether this destruction was the punishment of God for their sins. If the destruction was God's punishment for sin, they had to consider how to know God's will with certainty to avert similar disasters in future. This resulted in many significant reformulations of important theological ideas and religious practices. Various Jewish groups debated questions about the meaning and practice of the Torah and about the authority to interpret it (Carter 2000:140; Cohen 2006:123; Foster 2004:2; Saldarini 1994:5). The temple-based worship was replaced by small localised groupings with a mutual emphasis on Torah conservation and interpretation (Neusner 1979:42; Van Aarde 2011:46). The Law emerged as a central symbol in Jewish religion. Overman (1990) writes:

The law now emerged as the central symbol for post-70 Judaism. Who was recognized as the authoritative interpreters had a great deal to do with who emerged as the accepted and established movement. (p. 69)

The group that would be recognised as the most authoritative and accurate interpreters of the Law, would become the dominant force. Josephus (Jewish Wars, 1.5.1; 2.8.14) described the Pharisees as the most accurate interpreters of the Law.

The importance of the Law was obviously nothing new. Since the time of the Deuteronomistic historian there had been a continuous urge to a more exact observance of the Law (Foster 2004:49). Yet, in the fragmented Jewish society of the 1st century $\mathrm{CE}$, this observance became more intense. Competing groups who each regarded themselves as the righteous few used the Law to legitimate their own position against their adversaries.

The Essenes believed they understood the Law correctly and that others in Israel, especially in the temple, failed to understand it. According to 1QS9, God has 'concealed the teaching of the Law from the men of falsehood, but shall impart true knowledge and righteous judgement to those who chose the Way'. The true meaning of the Law was explicated by the Teacher of Righteousness. With his interpretation of the Law, the Essene community validated their own beliefs and practices and denounced those of other groups, specifically of the Jerusalem leaders.

Other Jewish documents from the late Second Temple Period until the 1st century CE reveal similar sentiments. Like the Essenes, 1 Enoch claims that the enemies of its community do not follow the Law correctly and lead people astray with false versions of the Scripture (1 En 99:12), whilst its own community understood their mysteries and made them available for the chosen community (1 En 92:1; 93:1). The Psalms of Solomon also attacks the Jewish leaders as people who violated and corrupted the Law (Ps Sol 4:1, 8, 22), whilst its own community is regarded as the faithful people who remain true to God's Law (Ps Sol 14:10). In 2 Baruch, Baruch himself emerges as God's agent who truly instructs the righteous community (2 Bar 38:1-4). Baruch is paralleled with Moses, as Baruch left his people and ascended Mount Zion to receive God's instructions. Like Moses, Baruch is portrayed as God's lawgiver. In 4 Ezra 14, Ezra appears as Moses redivivus: 'I revealed myself in the bush, and spoke to Moses, ... So too I now give this order to you' (v. 3-7).

Because of how important the Torah was to the people of God, the interpretation of it became a feature of the division in Judaism. The different groups studied the Law in minute detail. They identified 613 commandments in the Torah (248 positive and 365 negative) (Morris 1992:107; Neusner 2006:77). It was their desire to meet the specific obligations of these commandments, which resulted in competitive disputes as to what they meant in practice. With a legalistic turn of mind, each group claimed to be living according to the principles of the Torah. Obviously, this implied that other groups were not doing so:

In such polemic the need for a group to find in the Torah its own self-affirmation had the inevitable corollary of making the Torah an instrument by means of which one group condemned another. (Dunn 2003:292)

In many cases a study of what a group rejects, reveals what the group is in itself.

In Pharisaic Judaism the Torah was not limited to the written version. Pharisaic Judaism entertained the concept of a dual Torah, which refers to the written and oral law (Neusner 1994:5-7; 2007:111; Schiffman 2012:424). The Pharisaic dual Torah implies an oral supplement to the written Torah, which provides guidelines on how to apply the written Torah in daily life. This approach earned them the title and identity of 'Judaism of the dual Torah'. The oral law was preserved through the oral tradition and the rabbis. According to the Babylonian Talmud, ${ }^{4}$ a rabbi was considered the equivalent

4.Although the Babylonean Talmud was only formalised in written form in late antiquity (3rd to 5 th century CE) (Cohen 2006:5), it probably reflects the sentiments of earlier rabinnic sages. 
of a scroll of the Torah (Neusner 1994:6). This Talmud states: 'He who sees a disciple of a sage who has died is as if he sees a scroll of the Torah that has burned' (Y. Moed Qatan 3:7.X), and 'An elder who forgot his learning because of some accident which happened to him - they treat him with the sanctity owed to an ark [of the Torah]' (Y. Moed Qatan 3:1. $\mathrm{XI}$ ). The Essene community, however, distinguished between the 'revealed law' (the written Torah) and the 'hidden law' derived from their own exegesis of the written law and only known by their community. Both of these groups believed that this second Torah was divinely inspired (Schiffman 2012:424).

The social location of Matthew is linked to the evangelist's view of the Law. Barth (1963) remarks:

Matthew does not share the understanding of the law in the Rabbinate but rather opposes the Rabbinate face to face. But it will still not be correct to speak of a lex nova because the identity with the law of Sinai is not strongly emphasised. (p. 159)

With regard to Matthew's discussion of the Law, the evangelist developed a subtle dialectic with its opponents, presumably some village teachers of the Law (scribes) in the process of establishing a Pharisaic rabbinate. Matthew's Jesus strongly critiques the Pharisees' oral traditions (e.g. Mt 15:1-9) $)^{5}$ and questions their interpretations of the Torah (e.g. v. 21-47). He denounces their righteousness with an emphasis on personal integrity (e.g. 5:20; 6:1). These traditional teachers of the Law presumably felt that their core values were undermined by Jesus' followers. This probably led to Matthew's community being accused of abrogating the Law. The Matthean Jesus rejects such accusations in texts such as 5:17-19. The Matthean community, as a sibling of the local Pharisaic Judaism, strived to establish its claims of following the true interpretation of the Law (Foster 2004:28). Matthew presents Jesus as a unique and authoritative teacher of the Law (cf. 7:28-29) who was in continuous dispute with Pharisees and teachers of the Law who concentrated on the minute interpretation of the Torah's commandments, but missed the true intention of the Law.

Matthew describes Jesus as the one who brought the definitive interpretation of God's will. Matthew claimed that Jesus provided the answer. Jesus superseded current understandings of the Law with his reinterpretation. In the Sermon on the Mount, Jesus is presented as a Moses type. In the beginning of the Sermon (5:1-2), the Sinai typology is significant (Loader 1997:165). This leads to an anticipation of a new revelation to be delivered by a new Moses. He had come to fulfil the Law (5:17). Matthew claims that 'He taught as one who had authority, and not as their teachers of the law' (7:29). Therefore, Matthew reports the words of Jesus: 'All authority in heaven and on earth has been given to me

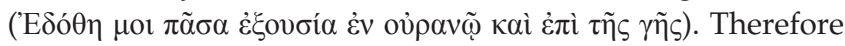
go and make disciples ... teaching them to obey everything

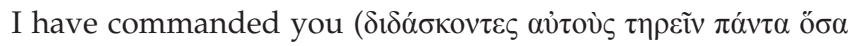

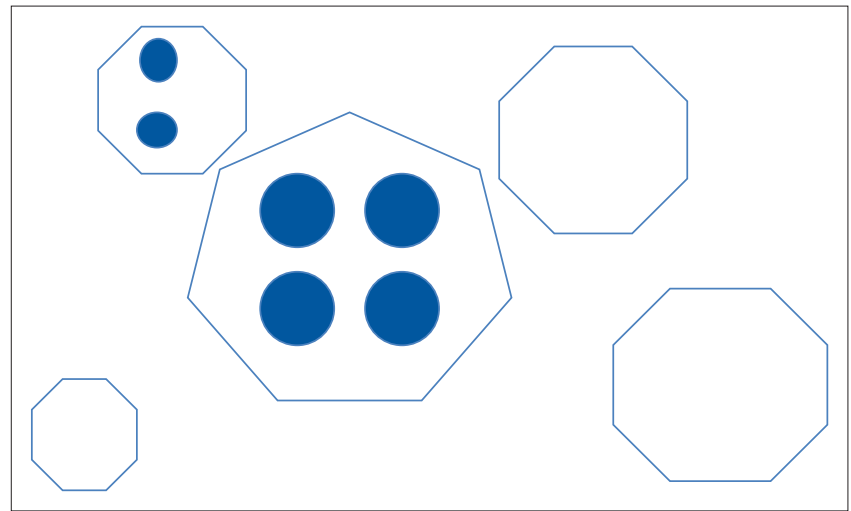

FIGURE 1: Dynamics of a society.

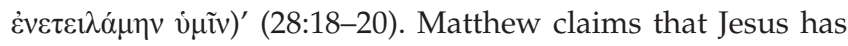
the authority to interpret the Scriptures. His interpretation provides the answer to the correct way of understanding the Scriptures. As followers of Jesus, Matthew sees himself and his community as the guardians of the correct understanding of the Law and the Prophets (Overman 1996:50). Jesus' interpretation of the Torah marked the identity of the Matthean community.

\section{The Torah as boundary marker}

The tension amongst the Jews was intensified by the fact that they struggled to maintain their identity within the Hellenistic culture and under the Roman Empire. The Hasmonean dynasty also showed a particular affinity for Greek culture (Wright 2013:311). This resulted in a strong tendency towards Jewish exclusivity. The Jews fended them from foreign influences in their struggle to maintain their identity (Saldarini 1994:13). They realised that purity was their means to protect their lifestyle from Gentiles and unfaithful Jews (Wright 2013:311). After the destruction of the temple, they had to maintain their holiness before God and they did this with purity practices and separation from the nations. The synagogue activities played an important role in this self-affirmation (Knight 2004:11). It was at this point that the distinction between Judaism in its diversity and Israelite religion became evident. ${ }^{6}$ Specific interpretation of the Torah was used to assure Jewish exclusivity and create group identity. Such emphases gave 'Judaism' its nationalistic, antiGentile and exclusive character (Dunn 2003:292).

The dynamics of a society can be illustrated by Figure 1 .

The society is depicted as a heptagon. Behaviour and thought that are considered as normal and authoritative (depicted as circles) are clustered within the society, the heptagon. The behaviour and thought of the society are controlled by those in powerful positions. The line inscribing the behaviour and thought could be considered as the boundary of that society.

6.Whilst the Israelite religion had a temple, Judaism had synagogues. The Israelite religion had priests, while Judaism had sages or rabbis. The Israelite religion had animal sacrifices, while Judaism had prayers. The Israelite religion was adhered to primarily in the homeland of Israel, while Judaism was found spread over the Roman Empire. However, the transition from the one to the other happened over a Roman Empire. However, the transition from the one to the other happened over a
period of time, although the destruction of the temple in $70 \mathrm{CE}$ could be regarded as a decisive event (cf. Cohen 2006:8-12). 
TABLE 1: Prominent passages.

\begin{tabular}{ll}
\hline Laws & Gospel \\
\hline Identity marker & Matthean reference \\
Sabbath & $12: 1-14$ \\
(Circumcision) / baptism & $28: 19$ \\
Dietary laws & $15: 1-20$ and (9:10-13) \\
Purity & $8: 1-4 ; 9: 18-26$, \\
\hline
\end{tabular}

Other social groups (depicted as octagons of differing sizes) are dispersed around the society, each with their own patterns of behaviour and thought. These groups may be related to the society or parts of it and can stand closer or further from the society.

Laws regarding the Sabbath, circumcision, diet and purity were foremost to form the behaviour and thought of the Jewish society (cf. Wright 2013:310). Observance of these laws was considered as normal and formed the identity markers of the society. Jewish religious leaders defended and enforced these identity markers, which resulted in boundary markers between Jews and Gentiles.

In Matthew's Gospel these laws or identity markers are recognisable, indicating their closeness to the Jewish society. However, it seems that the Matthean community challenged the way the rabbinic movement in their society interpreted these laws. They based their understanding on the teaching and activity of Jesus. The following table indicates most prominent passages where the first Gospel refers to or implies such laws (see Table 1).

\section{Sabbath}

The observance of the Sabbath was the clearest marker of identity in the Jewish community (Wright 2013:315-318). According to biblical evidence, it was a well-established feast by the early Second Temple Period (cf. Is 56:2; Neh 13:15-22). It was regarded as a sign of the covenant (Ex 31:14-17) with mention of its origins in the creation narrative (Gn 2:2-3). Even the Elephantine papyri records document concern for the Sabbath amongst the Jews in Egypt during the 5th century BCE. Nevertheless, the way the Jews observed the Sabbath varies, as questions were raised about what was permitted on the Sabbath. Practices varied concerning issues like marital sex, saving human and animal lives, conducting warfare, fasting and travelling. The Sabbath controversies in 12:1-14 signify a reinterpretation of the Sabbath Law by the Matthean community, serving as an identity marker of this community. Matthew's Jesus does not reject the Sabbath as such, but the Matthean Pharisees' halakah on the Sabbath.

\section{Circumcision}

Circumcision is another important Jewish identity marker.7 Circumcision had its roots in Genesis 17 and was demanded

\footnotetext{
7.The practice of circumcision, however, was not unique to the Israelites. According to Jeremiah 9:25-26 other Semitic groups such as the Edomites, Ammonites and to Jeremiah 9:25-26 other Semitic groups such as the Edomites, Ammonites and
Moabites were also practicing circumcision, but the Philistines are called the Moabites were also practicing circumcision, but the Phil
uncircumcised in a derogatory manner (Wright 2013:312).
}

for a male to be part of the covenant community. By performing this ritual with one's son, an individual passed the privileges and ethical responsibilities over to the next generation. Additionally, individuals who were not biologically related to Abraham could also be assimilated into the nation by way of circumcision (Wright 2013:311-314). Antiochus IV Epiphanes outlawed circumcision along with other identifiable Jewish customs. This resulted in the Maccabean revolt in die mid-second century BC (1 Macc 1:44-49, 60-63). The faithful in Palestine condemned the Jews who rejected circumcision (1 Macc 1:13-15; Josephus Ant. 12.241). When the Maccabeans defeated Seluecides and the Hasmonean Kingdom was established in Palestine, a ruling was imposed that all Jews had to be circumcised (1 Macc 2:46; Josephus Ant. 12.278; 13.257-258, 318-319). This illustrates how important circumcision was regarded in Second Temple Judaism. The importance of this ritual is also reflected in the Dead Sea Scrolls. According to $1 \mathrm{QH} 14.20$ the uncircumcised may not walk on God's holy path and 4Q458 declares that the uncircumcised will be destroyed in the last days. In Matthew a shift can be recognised. Matthew does not mention circumcision at all. One could argue (e.g. Saldarini 1994:157) that the reason why Matthew did mention circumcision suggests that he accepted the importance of circumcision. This, however, is unlikely. Other than in Luke (Lk 2:21), Matthew does not mention Jesus' circumcision. New gentile believers were not required to be circumcised, but to be baptised (28:19). They were not regarded as 'God-fearers' as the uncircumcised, but as full members of the community. It seems that baptism replaced circumcision to allow both males and females into their community.

\section{Dietary laws}

From the quantity of biblical texts devoted to food laws (e.g. Lv 11:1-47; Dt 14:2-20), it is clear that the Israelite diet was extremely important and formed another identity marker. Food laws were not simply related to dietary health, but also to covenantal purity. Although some Jews in the GrecoRoman period discarded some dietary laws in an effort to adapt to the surrounding cultures, Philo (Migr. 89-93) confirms that the general population remained diligent in keeping the food laws. In 15:1-20 Jesus states that what enters a person's mouth does not defile him or her, but what comes out of the mouth, signifying a reinterpretation of food laws.

In the Jewish society, eating with others was also strictly regulated. Sharing meals was a way of binding the community together by confirming identity. Eating with Gentiles were forbidden, although some Jews found it acceptable if a Jew hosted the dinner or brought his own food to the Gentile's house (Jdt 12:1-4, 19; Add Esth. 14:17; Josephus Life 14; Rm 14:1-2). Gentiles found the Jewish adherence to food laws anti-social and reclusive. Philostratus (Vit. Apol. 33) describes how the Jews set up walls between themselves and the Gentiles with their food laws. 3 Maccabees 3:4 states: 'they [the Jews] kept their separateness with respect to foods. For this reason they appeared hateful to some'. Matthew reveals 
a different attitude. In 9:9-13 the Pharisees blame Jesus for eating with tax collectors and sinners, but Jesus justifies himself with the words 'It is not the healthy who need a doctor, but the sick' and 'go and learn what this means: "I desire mercy, not sacrifice." For I have not come to call the righteous, but sinners.' This story in Matthew signifies a reinterpretation of the custom of table sharing.

\section{Purity}

Purity can be regarded as the fourth Jewish identity marker (Wright 2013:318-321). Jews developed distinct strategies to define, achieve and maintain purity as described in Leviticus, Deuteronomy and Ezekiel. Nevertheless, purity laws varied amongst Jewish groups in the Second Temple Period. A strict degree of purity was imposed in the Essene community as they maintained a lifestyle similar to the priesthood of the Zadokite temple. The Essene community regarded themselves as the temple. To form part of the community one had to maintain purity by adhering to the priestly code. They treated their meals as holy food eaten outside the temple by the priests; they abstained from wine, because it was prohibited to drink wine in the temple; and they avoided sexual intercourse due to the impurity caused by semen (CD 12.1). The first Gospel reflects issues regarding purity. Jesus touches a leper (8:3); a woman with blood flow touches him (8:20); Jesus enters the room of a dead girl and takes her by the hand (8:25), and yet, no mention is made of Jesus undergoing purification rites afterwards. The Pharisees and scribes charge Jesus as his disciples do not wash their hands before eating (15:2), but Jesus counter-charges the Pharisees by saying that they break the command for the sake of their tradition (v. 3) and asserts that eating with unwashed hands do not defile a person (v. 20). Jesus assures his followers that those who are pure at heart will see God (5:7-8). From these accounts it seems that Matthew's Jesus also reinterprets purity regulations for his followers.

From this overview of these four identity markers and references to them in the first Gospel, it seems that Matthew's Jesus reinterpreted these markers. It seems that the Matthean community was still closely related to the Jewish society, although their deviance is apparent. Whilst the identity markers normally served to separate Jews from Gentiles, the different interpretation of these laws resulted in a separation between the Matthean group and the rest of the Jewish society. The character of the boundary marker between insiders and outsiders changed. The Matthean community differentiated them from the Pharisaic-rabbinic movement they encountered.

The changes, introduced by the Matthean community into their interpretation of the identity markers, are typical of deviant groups (Saldarini 1994:111). Matthew narrates the story of Jesus and his disciples to defend and establish the respectability of their 'deviant' behaviour. The Gospel challenges the conventional standards and delegitimises the religious leaders who control the definitions of what is considered to be normal and deviant.
This shift in identity of the Matthean community can also be recognised in their acceptance of Gentiles into their midst. ${ }^{8}$ In contrast to the exclusivity between Jews and Gentiles, the first Gospel reveals an open door to Gentiles. The Gospel concludes with the responsibility of the community to spread the teaching of Jesus to all nations. ${ }^{9}$

In the verses, directly before discussing Jesus' teaching on the Torah, Matthew reports the words of Jesus: 'You are the salt of the earth ... you are the light of the world ...' (5:1316). It appears that Matthew drew a direct link between the interpretation of the Torah and the faithful people's responsibility to witness to the world. The Matthean community's decision to carry the proclamation of Jesus to the Gentiles must have created much tension with the synagogue, which used the Torah as means to maintain Jewish exclusivity (Repschinski 2000:27). Luz (1990:84) proposes that Matthew elected himself as advocate to defend his community's decision for the gentile mission. An alternative interpretation of the Torah is proposed to combat Judaist exclusivism. In light of the Great Commission (28:20), the basic entrance requirement to the Matthean community was belief in Jesus and acceptance of his teaching with the accompanying baptism (Saldarini 1994:79). The traditional Jewish boundary markers, Sabbath observance, circumcision, food laws and purity are not mentioned in this context.

\section{Conclusion}

By reading the Gospel of Matthew one can somehow picture the community in which the gospel was created and for whom it was intended. As this picture is a construct mainly based on the internal witness of the first Gospel that is intended as an internal document to its own community, opponents are presented from a specific perspective.

It seems that the crisis of $70 \mathrm{CE}$ led to a reconsideration of the correct interpretation of the Torah. The Torah formed an important issue in the variety of Jewish movements. Rivalling deviant factions frequently defended their position based on their group's form of adherence to the Torah, whilst denouncing their opponents at the same time. Whilst Judaism constructed new societies in the synagogues based on their Torah interpretation, the Matthean community was structured as a church and based their Torah observance on what Jesus had taught them. The Sabbath observance, circumcision, dietary and purity laws functioned as identity markers to separate Jews from Gentiles. Matthew's Jesus reinterprets these cultic practices to set alternative boundaries. Whilst Judaism(s) started to use the Torah as means to fend themselves off from foreign influences, the Matthean community propagated gentile mission. This

8.The opposition of the synagogue could have been a contributing factor in the community's outreach to Gentiles (Brown 1997:215. Although it seems that gentile mission rejected in 10:5-6 and 15:24, Jesus in his farewell words commands mission to the Gentiles (28:19)

9.It has often been suggested that Matthew's Gospel was written in Antioch, though conclusive evidence is lacking. According to Acts this was the city in which the followers of Jesus were first called 'Christians' (Ac 11:26). They were missionfollowers of Jesus were first called 'Christians' (Ac 11:26). They were mission-
minded, as it was this community who sent Paul and Barnabas out on their first missionary journey (Ac 13). 
decision intensified their conflict with the synagogue, who accused them of not adhering to the Torah. Matthew defended the position of his community by claiming that Jesus, who brought the authoritative interpretation of the Torah, ordered them to do so. Jesus is presented as the new Lawgiver (Moses). Matthew thus comforted his community, who felt insecure as a result of being rejected by their Judaistic sibling they encountered in their villages.

\section{Acknowledgements Competing interests}

The author declares that he has no financial or personal relationship(s) that may have inappropriately influenced him in writing this article.

\section{References}

Barth, G., 1963, 'Matthew's understanding of the Law', in G. Bornkamm, G. Barth \& H.J. Held (eds.), Tradition and interpretation in Matthew, pp. 59-164, SCM, London.

Brown, R.E., 1997, An introduction to the New Testament, Doubleday, New York.

Carter, W., 2000, Matthew and the margins. A socio-political reading, Academic Press, Sheffield. (JSNT Supplement Series, Book 204).

Cohen, S.J.D., 2006, From the Maccabees to the Mishnah, 2nd edn., John Knox Press, London.

Dunn, J.D.G. 2003. Jesus remembered. Christianity in the making, vol. 1, Eerdmans, Grand Rapids, MI, Cambridge.

Foster, P., 2004, Community, law and mission in Matthew's Gospel, Mohr Siebeck, Tübingen. (WUNT, 2, Reihe 177).
Knight, J., 2004, Jesus: an Historical and Theological investigation, T\&T Clark, London, New York.

Loader, W.R.G., 1997, Jesus' attitude towards the Law. A study of the Gospels. Mohr Siebeck, Tübingen. (WUNT, 2, Reihe).

Luz, U., 1990, Matthew 1-7. A commentary, T\&T Clark, Edinburgh.

Morris, L., 1992, The Gospel according to Matthew, Grand Rapids, Eerdmans.

Neusner, J., 1979, 'The formation of Rabbinic Judaism: Yavneh form 70-100', in H. Temporini \& W. Haase (eds.), Aufstieg und Niedergang der Römischen Welt: Geschichte und Kultur Roms im Spiegel der Neueren Forshung, pp. 3-42, Walter Geschichte und Kultur Roms im
de Gruyter, Berlin, New York.

Neusner, J., 1994, Introduction to rabbinic literature, Doubleday, New York, London, Toronto, Sydney \& Auckland.

Neusner, J., 2006, Judaism, the basics, Routledge, London, New York.

Neusner, J., 2007, Judaism, Routledge, London, New York.

Overman, J.A., 1990, Matthew's Gospel and formative Judaism. The social world of the Matthean community, Fortress Press, Minneapolis, MN.

Overman, J.A., 1996, Church and community in crisis: The Gospel according to Matthew, Trinity Press, Valley Forge, PA.

Repschinski, B., 2000, The controversy stories in the Gospel of Matthew: Their redaction, form and relevance for the relationship between the Matthean community and formative Judaism, Vandenhoeck \& Ruprecht, Göttingen. http:// dx.doi.org/10.13109/9783666538735

Saldarini, A.J., 1994, Matthew's Christian-Jewish Community, University of Chicago, Chicago, London.

Schiffman, L.H., 2012, 'Early Judaism and Rabbinic Judaism', in J.J. Collins \& D.C. Harlow (eds.), Early Judaism. A comprehensive overview, pp. 420-434, Eerdmans, Grand Rapids, MI.

Stanton, G.N., 1992, 'The communities of Matthew', Interpretation 46(4), 379-391. http://dx.doi.org/10.1177/002096439204600406

Van Aarde, A., 2011, 'On earth as is in heaven - Matthew's eschatology as the Kingdom of heavens that has come', in J.G. van der Watt (ed.), Eschatology of the New Testament and some related documents, pp. 35-63, Mohr Siebeck, Tübingen.

Wright, A.T., 2013, 'Jewish identity, beliefs, and practices', in J.B. Green \& L.M. McDonald (eds.), The world of the New Testament. Cultural, social and historical contexts, pp. 310-423, Baker, MI. 